\title{
Importance of Modern Communication Technologies in Monitoring Compliance of Patients with Chronic Myeloid Leukemia
}

1 Nikolina Matić

2 Ivica Matić

1 School of Nursing Vrapče, Zagreb, Croatia

2 School of Nursing Mlinarska, Zagreb, Croatia

Article received: 22.10.2019.

Article accepted: 04.12.2019.

DOI: $10.24141 / 2 / 3 / 2 / 3$

Author for correspondence:

Ivica Matić

School of Nursing Mlinarska

Mlinarska 34, Zagreb, Croatia

E-mail: ivica.matic3@skole.hr

Keywords: nursing, information and communications technology, compliance

\section{Abstract}

Compliance is a term that applies to the patient's ability to correctly follow advice and instructions regarding medications, diet, and activity. The nurse, as an important factor in the multidisciplinary team, has a special responsibility in monitoring the patient's compliance. It is essential for patients with chronic malignancies, such as chronic myeloid leukemia, which is nowadays mostly treated successfully by continuous and regular monitoring and application of therapy.

The aim of the present study was to determine whether the nurse's communication with patients, which implies the use of information and communications technology, affects compliance.

The study was conducted on a sample of 50 outpatients at the Department of Haematology of the University Hospital Centre Zagreb. The respondents used some form of modern communication for three weeks and were re-interviewed for compliance.

The use of modern information technology enhances patient compliance. Those who were reminded significantly improved the regularity of their check-ups. After the intervention, the respondents considered reminders useful in encouraging them to take medicines more regularly and to attend check-ups. 


\section{Introduction}

Malignancies are a significant public health problem in Croatia, as in the rest of the developed world. Considering the distribution of new cancer patients with leukemia, lymphomas make up $5 \%$ in both sexes (1). The treatment of these diseases is extremely costly because it requires the use of high doses of chemotherapy, often including transplantation of hematopoietic stem cells (2). The multidisciplinary approach in the care of patients with chronic myeloid leukemia (CML) recognizes and involves the nurse as an important partner. There are several important elements of nursing in the care for a patient with CML (3):

1. the patient's lack of knowledge; it is important that the nurse thoroughly explain the health state to the patient, as well as the importance of taking medication and overall treatment, and to make daily recommendations. The patient should be referred to any community resources they can use.

2. compliance - it is necessary to pay attention to the factors that enhance good patient compliance such as motivation, belief in the ability of controlling the condition, quality recommendations, and availability of resources. Once established, good compliance should be monitored continuously, as the patient may be at risk of losing the will to co-operate. Therefore, it is crucial to describe to the patient the benefits of collaborating and adhering to health recommendations.

3. the improvement of communication has a great importance for the relationship between the nurse and the patient, and is essential in addressing clinical, psychological, and social needs. An individualized approach to the patient, as well as, more recently, modern information and communications technology (ICT), form the basis for achieving good communication. Since CML is a malignant disease that is today most successfully treated with continuous and regular treatment, the importance of nursing interventions is at the forefront of educating patients and encouraging compliance. It is essential to be informed about the current condition and to inform the patient that col- laborative patients are three times more likely to have good therapy outcomes in comparison with non-compliant patients (4). Despite the knowledge about patient compliance and the possibilities of its improvement, numerous studies have shown poor compliance results $(5,6)$. Mann et al. have examined the compliance of patients with CML with imatinib treatment, and the results showed that one third of the patients were considered non-compliant (7).

Practically all modern forms of ICT can help follow the recommendations for achieving the set goals of better cooperation. When the first symptoms appear, patients are more likely to resort to online information. However, it is crucial that they are valid and reliable, as they will have an increasing impact on medical practice under the influence of growing computerization (8). According to some studies, nurses still have insufficient knowledge in the field of ICT, although they have the motivation for acquiring new knowledge (9). Communication based on new technologies in the relationship between healthcare professionals and patients is not very common. Telephone calls still have primacy. According to a New Zealand study, $70 \%$ of doctors never use e-mail to communicate with their patients (10). Questioning GPs about the use of email in patient care, Car and Sheikh found that doctors used e-mail in communication with $1-5 \%$ of their patients (11). On the other hand, patients' opinions on the use of ICT with health professionals are interesting. According to one study, more than one third of the patients were willing to pay extra for this type of care (12). It is certain that patient attitudes towards ICT correspondence with healthcare professionals has an impact on the relationship. A study conducted in Norway found that, on average, one e-mail per year resulted in reduced arrival at the office for one visit per patient per year (13). Literature analysis provides unambiguous conclusions about the benefits of using ICT (1014). Nevertheless, patient communication with the staff in the healthcare system using ICT does not follow its growth in general use. Nurses encounter the problem of poor co-operation in their daily work with patients with chronic diseases. There are many reasons for poor co-operation, and nursing care interventions lead to discovering the causes and finding solutions. It seems that the use of ICT could have an impact on compliance, especially in younger patients. 
Therefore, the aim of the present study was to determine the extent to which non-compliance in the care of CML patients at University Hospital Centre (UHC) Zagreb is expressed and whether the manner of communication influences patient compliance. The hypothesis is that modern forms of communication improve the compliance of patients with CML.

\section{Methods}

This prospective intervention study was conducted on a group of 50 outpatients at the polyclinic section of the Department of Haematology, UHC Zagreb, from January to April 2014. Each respondent was informed of the basic methods of conducting and participating in the study. The sample includes all adult patients with CML. Excluded from the sample were persons under 18 years of age, all patients with significant comorbidities, infectious diseases, severe anaemia, and patients older than 70 years of age due to the fact that they are mostly looked after by others, which can affect their compliance. On the basis of the first survey results, an intervention subgroup that included those who did not evaluate their compliance as completely regular was formed. From a total of 27 respondents who estimated their compliance as incomplete, five of them did not use ICT, so the final sample included 22 patients, who included their specific identifier for electronic communication (e-mail address, cellular phone number, Facebook profile) at the end of the questionnaire, which was then used to contact them. The subgroup used some form of modern communication (e-mail, SMS, Facebook, WhatsApp). Messages in the form of a reminder to take medications were sent every morning, and patients were reminded to come for check-ups or collect new doses of medication seven days prior and a day before a scheduled appointment. The reminder sent this message: "Do not forget to take your daily dose of medication/to collect your new dose of medication/to come to the scheduled appointment." The respondents were interviewed again three weeks after the intervention. The survey was created using the Google Docs web application, and respondents were surveyed online, which made it anonymous. The obtained results are processed in the form of absolute and relative frequencies, shown in

tables and charts made in MS Excel 2007. The values were given as mean (M), standard deviation (SD) and range as minimal (min.) and maximal (max.) response on a 5-point scale. Differences between the groups were tested by the paired samples t-test. P-values $\leq 0.05$ were considered statistically significant. All analyses were performed using the online Social Science Statistics resources available from https://www. socscistatistics.com.

\section{Results}

\section{Overall assessment of patient compliance}

Participants evaluated their compliance on a fivepoint scale measuring cross-domain adherence to recommended treatment. Patients mostly cooperate when it comes to the regularity of collecting new doses of medications, with the incidence of forgetting to take the daily dose of medication varying from cases when it occurred every day to several times per week (grades 1-3) in 32\% of patients, which represents the most non-cooperative domain (Table 1 ).

\begin{tabular}{|c|c|c|c|c|c|}
\hline \multirow{2}{*}{$\begin{array}{l}\text { Self-reported } \\
\text { variable } \\
(\mathrm{N}=\mathbf{5 0})\end{array}$} & \multicolumn{5}{|c|}{$\begin{array}{l}\text { not at all compliant }(\mathbf{1}) \rightarrow \\
\text { completely compliant }(\mathbf{5})\end{array}$} \\
\hline & $\begin{array}{c}1 \\
N(\%)\end{array}$ & $\begin{array}{c}2 \\
N(\%)\end{array}$ & $\begin{array}{c}3 \\
N(\%)\end{array}$ & $\begin{array}{c}4 \\
N(\%)\end{array}$ & $\begin{array}{c}5 \\
N(\%)\end{array}$ \\
\hline $\begin{array}{l}\text { Overall } \\
\text { compliance }\end{array}$ & $\begin{array}{c}0 \\
(0)\end{array}$ & $\begin{array}{c}0 \\
(0)\end{array}$ & $\begin{array}{c}4 \\
(8)\end{array}$ & $\begin{array}{c}23 \\
(46)\end{array}$ & $\begin{array}{c}23 \\
(46)\end{array}$ \\
\hline $\begin{array}{l}\text { Regularity of } \\
\text { controls }\end{array}$ & $\begin{array}{c}0 \\
(0)\end{array}$ & $\begin{array}{c}0 \\
(0)\end{array}$ & $\begin{array}{c}0 \\
(0)\end{array}$ & $\begin{array}{l}27 \\
(54)\end{array}$ & $\begin{array}{l}23 \\
(46)\end{array}$ \\
\hline $\begin{array}{c}\text { Forgetfulness to } \\
\text { take a } \\
\text { daily dose }\end{array}$ & $\begin{array}{c}4 \\
(8)\end{array}$ & $\begin{array}{c}5 \\
(10)\end{array}$ & $\stackrel{7}{7}$ & $\begin{array}{l}12 \\
(24)\end{array}$ & $\begin{array}{l}22 \\
(44)\end{array}$ \\
\hline $\begin{array}{c}\text { Taking } \\
\text { medications } \\
\text { at the wrong } \\
\text { time }\end{array}$ & $\begin{array}{c}4 \\
(8)\end{array}$ & $\begin{array}{c}0 \\
(0)\end{array}$ & $\begin{array}{c}5 \\
(10)\end{array}$ & $\begin{array}{c}24 \\
(48)\end{array}$ & $\begin{array}{l}17 \\
(34)\end{array}$ \\
\hline $\begin{array}{l}\text { Regularity in } \\
\text { collecting } \\
\text { new doses of }\end{array}$ & $\begin{array}{c}4 \\
(8)\end{array}$ & $\begin{array}{c}0 \\
(0)\end{array}$ & $\begin{array}{c}0 \\
(0)\end{array}$ & $\begin{array}{c}5 \\
(10)\end{array}$ & $\begin{array}{c}41 \\
(82)\end{array}$ \\
\hline
\end{tabular}




\section{Individual domains of compliance before and after the intervention}

Out of the total number of respondents who used some form of ICT reminder for cooperation before the intervention, the regularity of their check-ups was assessed as mostly irregular. After the intervention, regularity was significantly greater: $69 \%$ of the respondents improved their compliance and it was completely regular. The regularity of check-ups was significantly improved after the intervention (Table 2).

Responses to a survey questionnaire assessing the timelines of taking medication showed that $23 \%$ of respondents often forgot to take medications on time, while after the intervention this was reduced to $14 \%$. There were no significant differences in the mean score of forgetting to take medications on time before and after the intervention (Table 3).
Before the intervention, $23 \%$ of the respondents forgot to take the daily dose several times during the week, whereas after the intervention, this was reduced to $14 \%$. Also, before the intervention, $27 \%$ of the respondents never forgot to take their daily dose of medications, whereas after the intervention this increased to $54 \%$. There were no significant differences in the mean score of forgetting to take the daily dose of medications before and after the intervention (Table 4)

The regularity in collecting new medication doses was rated as significantly worse after the intervention because $14 \%$ of the respondents began to sometimes irregularly collect new doses of medications. There is an equal percentage of respondents who, despite the intervention, rarely irregularly collect a new dose in $23 \%$ of cases. Ultimately, $63 \%$ of the respondents had complete regularity after the intervention (Table 5).

\section{Table 2. The regularity of check-ups before and after the intervention}

\begin{tabular}{|c|c|c|c|c|}
\hline $\begin{array}{l}\text { How would you rate the regularity } \\
\text { of your previous check-ups?* }\end{array}$ & $\begin{array}{l}\text { Before the intervention } \\
\qquad(\mathrm{N}=22)\end{array}$ & $\begin{array}{l}\text { After the } \\
\text { intervention }(\mathbf{N}=22)\end{array}$ & $\mathbf{t}$ & $\boldsymbol{p}$ \\
\hline M & 3.00 & 4.32 & 5.937 & $0.001^{\star *}$ \\
\hline SD & 0.00 & 1.04 & & \\
\hline scale min. (response \%) & $3(100)$ & $2(4)$ & & \\
\hline scale max. (response \%) & - & 5 (69) & & \\
\hline
\end{tabular}

\section{Table 3. How often do you forget to take your medications on time?}

How often do you forget to take your medications on time?

M

SD

scale min. (response \%)

scale max. (response \%)
Before the intervention

( $N=22)$

3.55

0.86

2 (23)

4 (77)
After the

intervention $(\mathbf{N}=22)$

\subsection{7}

0.75

2 (14)

5 (4)

scale: very often $(1) \rightarrow$ never (5)

\section{Table 4. Forgetfulness to take a daily dose of medications}

\begin{tabular}{|c|c|c|c|c|}
\hline $\begin{array}{l}\text { How often do you forget to take } \\
\text { your daily dose of medications? }\end{array}$ & $\begin{array}{l}\text { Before the intervention } \\
\qquad(\mathrm{N}=22)\end{array}$ & $\begin{array}{c}\text { After the } \\
\text { intervention }(\mathrm{N}=22)\end{array}$ & $\mathbf{t}$ & $\boldsymbol{p}$ \\
\hline M & 3.73 & 3.95 & 1.555 & 0.135 \\
\hline SD & 1.12 & 1.21 & & \\
\hline scale min. (response \%) & $2(23 \%)$ & $3(14 \%)$ & & \\
\hline scale max. (response \%) & $5(27 \%)$ & $5(54 \%)$ & & \\
\hline
\end{tabular}




\section{Table 5. Regularity in collecting new doses of medications}

$\begin{array}{ccccc}\begin{array}{c}\text { How would you rate the regularity } \\ \text { in collecting new doses of } \\ \text { medications? }\end{array} & \begin{array}{c}\text { Before the intervention } \\ (\mathbf{N}=\mathbf{2 2})\end{array} & \begin{array}{c}\text { After the } \\ \text { intervention (N=22) }\end{array} & \text { t } & \text { p } \\ \text { M } & 4.77 & 4.50 & -2.806 & 0.010^{* *} \\ \text { SD } & 0.43 & 0.74 & \\ \text { scale min. (response \%) } & 4(23) & 3(14) & \\ \text { scale max. (response \%) } & 5(77) & 5(63) & \end{array}$

*scale: completely irregular (1) $\rightarrow$ completely regular (5)

**statistically significant

\section{Table 6. Importance of a nurse in overseeing the medication intake}

How important is a nurse in overseeing medication intake?

$\mathrm{M}$

SD

min. (response \%)

max. (response \%)
Before the intervention

$(\mathrm{N}=22)$

3.77

1.27

1 (9)

4 (32)
After the

intervention ( $\mathbf{N}=\mathbf{2 2})$

$\begin{array}{lll}4.68 & 4.629 & 0.001^{* *} \\ 0.48 & & \end{array}$

$5(32)$

$5(68)$

*scale: not important at all (1) $\rightarrow$ extremely important (5)

In assessing the importance of nurses in overseeing medication intake, before the intervention $9 \%$ of respondents considered the function irrelevant, and the same percentage considered that function mostly irrelevant but sometimes important. After the intervention, none of the participants responded as they did before the intervention. Simultaneously, before the intervention, $32 \%$ of respondents estimated that function as very important, while after the intervention, $68 \%$ of respondents claimed they considered the function of a nurse extremely important. There were significant differences in the participants' opinions before and after the intervention (Table 6).

After the intervention, all participants felt that an ICT reminder would be useful for them to take medications more regularly (Figure 1 ).

When asked, "Would you be interested in continuing the reminder program with the use of ICT", $86 \%$ of the participants answered in the affirmative (Figure 2).

"How useful would an ICT reminder be to you?"

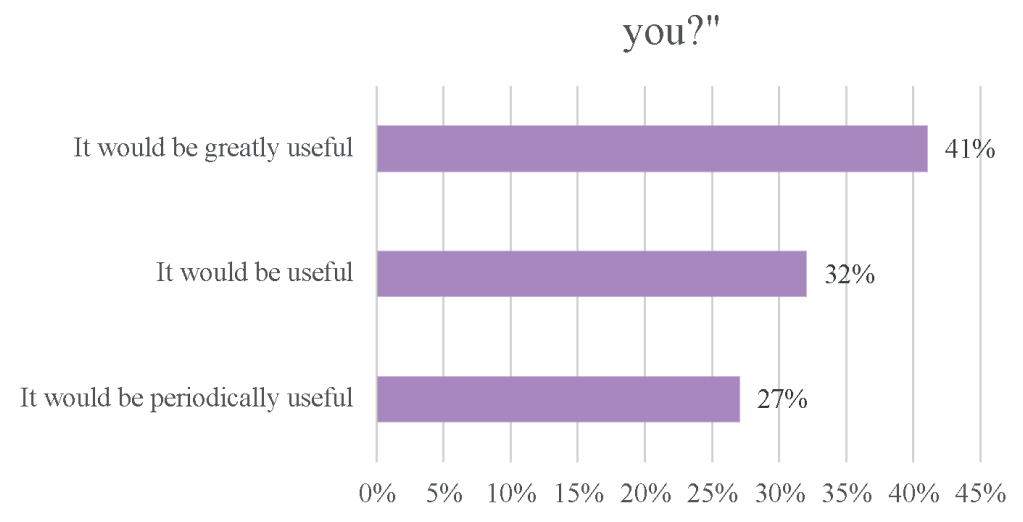

Figure 1. Usefulness of an ICT reminder 


\section{"WOULD YOU BE INTERESTED IN \\ CONTINUING THE REMINDER PROGRAM WITH THE USE OF ICT?"}

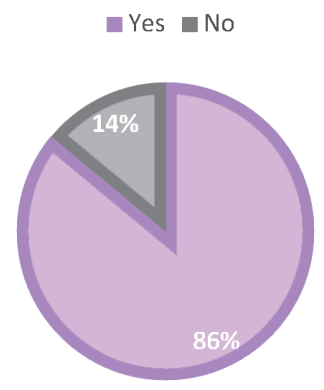

Figure 2. Interest in the use of an ICT reminder

\section{Discussion}

The use of ICT services such as e-mail and SMS in communication between patients and healthcare professionals is a relatively new trend that is of increasing importance. Among other things, the contribution of this communication method to the improvement of patient compliance is significant. Therefore, the aim of this study was to determine the degree of poor patient compliance and whether it was influenced by communication involving the use of ICT. While a significant percentage of patients regularly collect new doses of medications, most fail to take them at a certain time or sometimes even forget to take them entirely. Some studies have shown that GPs play the largest role in patient compliance and communication (13). All hematologic patients are expected to be consistent in taking therapy and consider compliance important to the outcome (14) because the use of costly therapy is the only hope for these patients. Respondents largely believe that a reminder would be useful for them to take medications more regularly.

Participants who received a reminder significantly improved the regularity of their check-ups. Before the intervention, they evaluated their compliance as mediocre, while after the intervention, in $70 \%$ of cases, they exhibited excellent cooperation regarding the regularity of coming for check-ups. Regularity in collecting new drug doses was rated worse after the intervention. Afterwards, when they arrived to collect their new dose of medication, the patients were asked to state their reasons for not collecting their medications on time. They often answered that during and after intervention they were better connected with nurses, and there were no problems with collecting new doses of medication on time. Patients were convinced they developed greater confidence in the professionals they interacted more often with, given the fact that they were more relaxed and knew that they could collect their dose at any time. Some studies have confirmed that frequent communication, for example via e-mail, contributes to increased confidence among patients (15).

In assessing the importance of a nurse in monitoring the administration of medication, $41 \%$ of respondents agreed that this function is often important and $32 \%$ that it is extremely important, and after the intervention $69 \%$ of respondents claimed that the function of a nurse is extremely important. This result is especially important since the research was conducted at the polyclinic department, from where the largest number of complaints about the work of nurses is received (16).

After the intervention, all respondents believed that an ICT reminder would be useful for them to take medications more regularly. After the intervention, $46 \%$ of the respondents confirmed that the reminder increased their regularity in taking their medications. A certain proportion of the respondents were largely cooperative in treatment, even before the intervention. When asked "Would you be interested in continuing the reminder program using information and communication technology", 86\% answered in the affirmative. Such a high percentage imposes the ne- 
cessity of developing new applications that will be tailored to the needs of the patient in order to improve compliance.

Further research should be carried out. It would be useful to determine which of the above modes of communication has the best effect. It would also be useful to monitor individual participants' responses to observe changes in individual cases.

\section{Conclusions}

On the basis of the study, it can be concluded that patient compliance is an occurrence that covers many areas which can be further employed using ICT. Participants who received a reminder significantly improved the regularity of their check-ups. Following the use of ICT, there was a decrease in non-cooperativeness regarding the timely administration of medicine, and a marked improvement in compliance regarding intake of daily doses of medications.

After the examination, patients considered a reminder useful for taking medications more regularly. At the same time, patients are encouraged to have a better sense of the importance of the nurse's role in monitoring compliance as a result of improved communication. It is necessary to promote a culture of communication using new technologies, conduct formal and informal education of healthcare professionals, and develop awareness of saving costs and professional time. Motivating health care professionals is crucial, and it is definitely important to use some model of change to increase the efficiency of the system and improve the quality of overall care using new technologies.

\section{References}

1. Hrvatski zavod za javno zdravstvo, Registar za rak Republike Hrvatske. Incidencija raka u Hrvatskoj 2015. Zagreb: Hrvatski zavod za javno zdravstvo; 2018. Croatian.

2. Labar B, Hauptmann E. Hematologija. Zagreb: Školska knjiga; 2007. Croatian.

3. Planinc-Peraica A, Mandac Rogulj I. Kronična mijeloična leukemija. Medix. 2012;18:212-218. Croatian.

4. Weisberg $E$, Manley $P W$, Breitenstein W, Brüggen J, Cowan-Jacob SW, Ray $A E$, et al. Characterization of AMN107, a selective inhibitor of native and mutant Bcr-Abl. Cancer Cell. 2005;7(2):129-41.

5. Sawyers CL. Chronic Myeloid Leukemia. N Engl J Med. 1999;340(17):1330-40.

6. Bennett, JM, Catovsky D, Daniel MT, Flandrin G, Galton DAG, Gralnick, $\mathrm{H}$, et al. The Chronic Myeloid Leukaemias: Guidelines for Distinguishing Chronic Granulocytic, Atypical Chronic Myeloid, and Chronic Myelomonocytic Leukaemia. Proposals by the French-American-British Cooperative Leukaemia Group. Br J Haematol. 1994;87(4):746-54.

7. Marin D, Bazeos A, Mahon FX, Eliasson L, Milojkovic D, Bua $M$, et al. Adherence is the critical factor for achieving molecular responses in patients with chronic myeloid leukemia who achieve complete cytogenetic responses on imatinib. J Clin Oncol. 2010;28(14):2381-8.

8. Matić I, Kern J, Matić N. Načela administracije. Zagreb: Školska knjiga; 2019. Croatian.

9. Matić I, Kern J, Svetić Čišić R, Matić N. Virtualna komunikacija u sestrinstvu - jesmo li spremni? Acta Med Croatica. 2014;68:7-14. Croatian.

10. Goodyear-Smith F, Wearn A, Everts $H$, Huggard P, Halliwell J. Pandora's electronic box: GPs reflect upon email communication with their patients. J Innov Health Inform. 2005;13(3):195-202.

11. Car J, Sheikh A. Email consultations in health care: 1 scope and effectiveness. BMJ. 2004;329(7463):435-8.

12. Interactive Harris. Patient/Physician Online Communication: Many patients want it, would pay for it, and it would influence their choice of doctors and health plans. Health Care News. 2002;2(8):1-4.

13. Bergmo TS, Kummervold PE, Gammon D, DahI LB. Electronic patient-provider communication: Will it offset office visits and telephone consultations in primary care? Int J Med Inform. 2005;74(9):705-10.

14. Abraham I, MacDonald K. Why are patients with chronic myeloid leukaemia (non-) adherent? $\mathrm{Br} J$ Cancer. 2012;107(6):901-3.

15. Leong SL, Gingrich D, Lewis PR, Mauger DT, George JH. Enhancing doctor-patient communication using email: a pilot study. JABFP. J Am Board Fam Pract. 2005;18(3):180-8.

16. Benceković Ž, Čerfalvi V, Režek B, Hadžić N, Vujanić E. Patient Complaints - a Tool for Improving Quality of Nursing Care. Croat Nurs J. 2018;2(2):129-39. 


\section{VAŽNOST SUVREMENIH KOMUNIKACIJSKIH TEHNOLOGIJA U PRAĆENJU SURADLJIVOSTI PACIJENATA OBOLJELIH OD KRONIČNE MIJELOIČNE LEUKEMIJE}

\section{Sažetak}

Suradljivost bolesnika pojam je koji označava pridržavanje pravila, savjeta i uputa dobivenih od zdravstvenih profesionalaca, a odnose se na primjenu lijekova, prehranu, aktivnosti te redovito kontroliranje. Medicinska sestra važan je čimbenik multidisciplinarnog tima u praćenju suradljivosti bolesnika, posebice oboljelih od kroničnih malignih bolesti kao što je kronična mijeloična leukemija. Bolest se danas uspješno liječi kontinuiranim i redovitim praćenjem i primjenom terapije, a važnost sestrinskih intervencija odnosi se i na poticanje i održavanje suradljivosti.

Cilj ovoga rada bio je utvrditi razinu suradljivosti bolesnika oboljelih od kronične mijeloične leukemije liječenih u KBC-u Zagreb te postojanje utjecaja modernih oblika komunikacija na suradljivost bolesnika.

Istraživanje je provedeno u Klinici za unutarnje bolesti KBC-a Zagreb na uzorku od 50 pacijenata koji su bili ambulantno liječeni. Samoprocijenjeno nesuradljivi ispitanici bili su podvrgnuti modernom obliku komunikacije tijekom tri tjedna te su ponovno anketirani.

Ispitanici koji su bili podvrgnuti podsjetniku znatno su popravili redovitost dolazaka na kontrolne preglede. Nakon provedene intervencije svi ispitanici smatraju da bi im bio koristan informatički podsjetnik u svrhu redovitijeg uzimanja lijekova te obavljanja kontrolnih pregleda.

Primjena modernih informacijskih tehnologija unaprijedila je suradljivost bolesnika.
Ključne riječi: sestrinstvo, informacijsko-komunikacijska tehnologija, suradljivost 